\title{
Lean Practices in the Process of New Product Development: Case of Study in a Food Industry Cooperative in Brazil
}

\author{
Simone Zamin \\ State University of Western Paraná, Brazil. \\ Leandro José Nichetti \\ UDC University Center, Brazil \\ José Antonio Cescon, Vinícius Abílio Martins \\ State University of Western Paraná (UNIOESTE), Brazil \\ Nilton César Lima \\ Federal University of Uberlândia - UFU, Brazil
}

Received: September 21, 2021 Accepted: October 26, $2021 \quad$ Published: October 28, 2021

doi:10.5296/jas.v9i4.19030

URL: https://doi.org/10.5296/jas.v9i4.19030

\begin{abstract}
This article presents a case study of employees' perception of Lean Manufacturing in the development process of new products at a Food Industry Cooperative in Brazil. A survey was applied in all areas of the company to measure the perception and understanding of employees regarding Lean Management and Lean Thinking. Also, to understand their knowledge of the principles and practices in developing new products in the company. The results showed that $76 \%$ of the responding employees have some understanding of lean management. It also shows low engagement by stakeholders and the board in the new product development process stages and weak integration between areas, such as environmental, engineering, and finance. On the other hand, RD\& area presented higher engagement, with $90 \%$ of its staff supporting this process.
\end{abstract}

Keywords: lean management; lean thinking; new products 


\section{Introduction}

The development of new products has been considered key for creating and sustaining competitiveness. For many industries, making efforts in this area is a strategic and necessary factor in operating. The implementation of new products supports the expectations of companies to increase their market share and improve their profitability (Jugend; Silva, 2014; Kotler, 2000).

According to Miguel (2009), the new product development process is an extensive number of activities and tasks that the organization must carry out and involve from the initial conception until its launch in the market.

Mature processes for product development in organizations increase the chance of success and financial return of their new products (Quintella; Rocha, 2007). Therefore, adequate planning, execution, and control of the development of new products produce, efficiently and effectively, satisfactory results for the organization. Thus, using a planned process to develop new products constitutes a vital management tool capable of better supporting product implementation and management decisions, reducing risks, and maximizing market opportunities (Lambin, 2013).

The company's competitive advantage is directly related to its ability to introduce new products and services. To do this, the company must have technological content and quality, performance, cost, and distribution characteristics that satisfy the demands of consumers. Developing new products that meet customer requirements or anticipate them is a crucial point for the longevity of organizations (Al-Ashaab; Sobek, 2013).

According to Nazareno et al. (2003), the factors that highly increased the productivity and competitiveness of organizations are the advances related to the development and implementation of techniques and tools for the Lean Production System.

Lean Manufacturing (LM) emerged as a business strategy that tries to meet management needs. Its concepts seek to implement, through simple processes, a way to reduce or eliminate waste, increase productivity through employee involvement and add Value to the customer final (Womack; Jones, 1997).

The industries in the food sector have heterogeneity of their products, which have degrees of perishability. They have different production times, supply problems, and diverse customers, quantities, and frequencies. They need to continually seek the balance of the risk of waste against reduced quality, minimizing the chances of storage and customer dissatisfaction (Monaj; Kumar; Gellynck, 2016).

In this context, this article focuses on the perception and understanding of LM concepts by people involved in the process of developing new products at Frimesa (Central Cooperative Company), seeking to answer the following question: In the design of a new product, are lean manufacturing concepts understood by the people involved?

This study sought to identify the level of knowledge of the company's employees about LM and their understanding of lean principles and practices in the development of new products 
at the Frimesa company.

The study justified itself by the fact that in previous research, the main approaches to the topic were:

i) how industries implement LM (Gurumurthy; Kodali, 2009; Fullerton; Kennedy; Widener, 2014);

ii) post-implementation evaluation of LM (Malmbrandat; Ahlstrom 2013; Lucato et al., 2014);

iii) barriers to the implementation of LM (Tortorella et al., 2018; Rymaszewska, 2014; Iris; Cebeci, 2014);

iv) integration of LM with other production systems (Cherrafi, 2016; Sanders; Elangeswaran; Wulfsberg, 2016; Gandhi; Thanki; Thakkar, 2018; Basu; Ghosh; Dan, 2018).

However, the gap to be examined is identifying the comprehensibility of these elements' objects of study in the company: LM.

The contributions of this study are on the perceptions of the main sectors and people involved in the company in the development of new products, considering that the industry has not implemented LM. It also contributes when approaching an agribusiness industry. Because of the results found, the company implemented the Thinking Lean program (Frimesa, 2021a). In this sense, the study contributes to previous research on Simons; Taylor (2007), Mahalik (2010), Dora et al. (2013), to understand the implementation of LM in a food processing industry.

The relevance and impact of this research are on the concern that industries should have when starting the LM implementation process. The industry must be sure that the personnel and sectors involved have the proper knowledge of LM meaning. The theoretical assumption demonstrates the need for prior training of the people involved in the employment of SCI before the beginning of the implementation (Mostafa; Dumrak; Solton, 2013).

The study in this article contains, in addition to the Introduction and Final Considerations, the Theoretical Framework, the Methodological Procedures, and the Presentation and Analysis of results, respectively, according to; third and fourth topics.

\section{Theoretical Framework}

\subsection{New Product Development Process}

The new product development process is a complex and iterative multi-stage decision-making process (Takahashi \& Takahashi (2007). This process involves many people, resources, knowledge, and many functions of the company. It is what makes the difference in the competitiveness of the companies' products in the long term. Therefore, the way the company carries out product development (its speed, efficiency, and quality of work) will determine its competitiveness. 
Developing new products requires planning, research, control, methods, and tools to integrate and optimize the different aspects involved. It will help all departments involved in developing new products to solve problems during development. It will also organize effectively and efficiently information and knowledge between functions and specialties involved. (Jugend; Silva, 2014).

Many companies seek to optimize their processes, eliminate waste, and create value throughout the production chain. Both Farfan (2020) and Stanke \& Murman (2001) said that the basic concepts of Lean Manufacturing, such as the focus on activities and processes that add value and consequently reduce work in activities that do not add value, have expanded to new levels. Beyond the factory floor. In a broader sense, lean concepts are applicable in the business context, extending to developing new products.

\subsection{Lean Manufacturing}

The Lean philosophy was developed in the 50s by Toyota (Japan) executive Taiichi Ohno (1912-1990). It comes from the need to establish a production system that could compete with the mass production systems of the giants North Americans. James P. Womack popularized LM expression with the help of Daniel T. Jones, and Daniel Roos, as Lean Thinking (LT) in their book: The Machine That Changed the World (1990).

For Bozdogan et al. (2000), Lean is not simply a set of practices used on the shop floor. It is a fundamental change within the company, affecting how people think and value, thus transforming behavior. According to Martins and Laugeni (2012), in LM, the main objective is to eliminate waste to obtain better results.

In this sense, according to Werkema (2006), adopting LM implies a change in the organizational culture of companies. It means that it is not enough to assume the tools and methods proposed by philosophy. It is also necessary to consider the so-called LT.

According to Murman et al. (2002), LT is a management philosophy applicable to any business to eliminate waste and create value. The knowledge of Value is the basis of what is a waste. This meaning is related to the characteristics of the products and services desired by the customer. LT seeks to eliminate activities that do not help achieve these requirements and are considered sources of waste.

Although the Lean concept has become very popular in mass production industries, this concept has been adopted more recently by other industrial and even service sectors (Fullerton; Kennedy; Widener, 2013).

Companies that seek to apply the LM philosophy, and LT, change the way they focus on their customers, enhancing the value of their services and products. These organizations that identify the demands of their customers reinvent themselves and adapt flexibly frequently. Such situations impose new types of financial information that attribute lean principles such as motivation, stability, continuous improvement, losses, and changes in the values understood by the customer (Santos, 2010).

Cantanhede (2014) stated that LT has expanded beyond the boundaries of automobile 
production, reaching other branches of production and may be applicable in the business context. Since its inception, LT has not only challenged mass production practices. It has also led to a rethink of a wide range of manufacturing operations and operations beyond manufacturing.

LT also seeks to offer a different cost model. It assumes that established companies set sales prices based on what they believe the market can support. Then work backward, determining acceptable costs for an adequate profit margin. In turn, lean companies see the prices and characteristics of products that have been offered to customers by established companies. Then they ask themselves: What is the cost of this product, free of waste and with unnecessary steps eliminated? It becomes the target cost. (Womack: Jones, 2004).

For Womack and Jones (1997), applying the five lean principles in processes throughout the company will lead to the "Lean" state. This Lean state eliminates waste in operations to develop products with a minimum portion of the material, time, and human effort costs. The five basic principles guide LT for every company:

1. Value Principle: precisely specify the Value.

2. Value Stream Principle: identify the value stream.

3. Flow Principle: make the identified value flow.

4. Pull System Principle: let the consumer pull the Value; and

5. Principle of Perfection: striving for perfection.

The success achieved by the Toyota company due to the creation of the Toyota Production System was a case study worldwide. It generated several new approaches, such as LT. Other companies applied this approach with success to various sectors. It develops a methodology adapted from LT to areas such as Lean Service, Lean Office, Lean IT, Lean Development, Lean Hospital, Lean Logistics, among others, are examples of the original application of Lean Manufacturing.

\subsection{Lean Thinking in New Product Development}

The LT applied in developing new products using the same logic but applied to the development process becomes more efficient with eliminating all losses. It has reduced its runtime (Tyagi et al., 2015).

The difference between applying lean principles in manufacturing concerning new products development is that the principles used in manufacturing focus on criteria that make use of a systematic process, where the product is easily known. In product development, however, there are difficulty viewing goals filtering information and necessary knowledge. The process allows innovation and reduced cycle time but uses methods that are difficult to measure, such as intellectual capital. Table 1 shows the application of lean principles in the manufacturing environment and product development. 
Table 1. Principles lean in manufacturing and product development environment

\begin{tabular}{|c|c|c|}
\hline Principles & Manufacturing & Product development \\
\hline Set Value & Visible at each step, goal set & Hard to see emerging goals \\
\hline Identify the value stream & Parts and material & Information and knowledge \\
\hline Make the process flow & Interactions are waste & $\begin{array}{l}\text { Interactions are often } \\
\text { beneficial. }\end{array}$ \\
\hline Pull system & Time driven & Driven by business needs \\
\hline Perfection & $\begin{array}{l}\text { Error-free and repeatable } \\
\text { process }\end{array}$ & $\begin{array}{l}\text { The process allows } \\
\text { innovation and reduces } \\
\text { cycle time }\end{array}$ \\
\hline
\end{tabular}

Source: Adapted from Machado; Toledo (2008)

Thus, the LM process is generally sequential, by nature, non-interactive and repetitive. However, developing new products is usually carried out in a network. It involves several areas and people with sequential processes, which can be highly interactive by generating products that add value to the customer with low waste rates. Initially, Lean principles comprise a set of techniques and tools that aim to improve the manufacturing process but quickly migrate to other areas within the company (Morgan; Liker, 2006).

The LT has evolved over decades, remaining with the concept of continuous improvement, also called Kaizen, becoming one of the central beliefs of the lean production system that began at Toyota. Continuous improvement is a problem-solving process that requires a series of tools, methods, and practices, which involves learning through the performance of activities. It uses the idea of LT based on processes to achieve a continuous flow of improvements, which is possible through the systematic education of workers and awareness of teamwork (Kilpatrick, 1997).

The lean approach to the development of new products is an asset. Its basis is the importance of adequately integrating people, processes, tools, and technologies to add value to consumers and society (Morgan; Liker, 2006). These elements are interrelated and interdependent. They influence the organization's ability to achieve its external goals (Hoppman et al., 2011; Wang, 2010).

The LT applied to the process of new product development has resulted in a significant interaction between the teams, as well as a minimization of the total development time, and provide greater dynamism and flexibility (Liker; Morgan 2011; León; Farris, 2011; Hoppman et al., 2011).

The definition of LT in developing new products also seeks to maximize added value to customers, shareholders, suppliers, and society, that is, to stakeholders. In this way, the central point is to develop the necessary activities, adding Value and eliminating/reducing 
unnecessary steps, and eliminating the use of incorrect/incomplete information that causes rework (Browning, 2001).

\section{Method}

As for approaching the problem, the classification of this research is quantitative. It used explanatory, descriptive statistics to analyze the results obtained and qualitative, regarding the interpretation of the results. The study relies on primary data collected directly through a structured questionnaire.

According to Gil (2010), this study is classifieds as applied research for its purpose. It will review the literature and by case study and thus confronting and equating with the proposed object. This research will generate data and new knowledge to the reality of LM and LT in new products development at Frimesa Central Cooperative. The company is in the extreme west of the state of Paraná, Brazil.

The bibliographic review supported the formulation of the questionnaire applied and analysis based on the results found, helping to formulate valuable considerations to the topic. Therefore, studies were researched in developing new products theme, aiming at LT in Frimesa Central Cooperative process. We searched for more expressive scientific articles in citations published in the primary Scopus ${ }^{\circledR}$ databases on the following topics: LM; LT; New Product Developments; LT applied to the New Product Development Process.

A structured questionnaire was used as a data collection instrument to obtain the desired data. This method has the advantage of being more versatile and low cost and makes it possible to get many data types (Mattar, 2001). The Likert scale was applied, requiring respondents to indicate their degree of agreement or disagreement with statements regarding the attitude in focus (Babbie, 1999). Mattar (2001) explains that each answer item is assigned a number that reflects the respondents' attitude towards each statement.

Thus, the case study was carried out in the company Frimesa Central Cooperative in 2020. All sectors/departments of the company receive a questionnaire. It asks for the level of education, the sector, and the position of each respondent. In this questionnaire, besides these two initial questions, the research is structured on the Likert scale, configured as follows: 03 (three) questions about the respondents' level of knowledge about the topic; 04 (four) questions seeking to identify the agreement of respondents on assertions of the subject under study; 05 (five) questions about the respondents' knowledge of the existence of the LM and LT process in the company; and 04 (four) questions about whether there is sharing with stakeholders in the development of new products in the company. At the end of 1 (one), the question seeks to know the respondents' perception of which company areas should be involved in new products development.

For the analyses, the average was calculated for each of the themes. After performing the normality test. The normality of a dataset is through its distribution because when the data is distributed symmetrically it is possible to draw a line vertically in the center of the distribution and they will be equal on both sides (Field, 2011). 


\section{Macrothink

To assess whether a distribution is normal or not, it is necessary to apply normality tests. In the present research data, as there are only 27 observations of each variable, the Shapiro-Wilk normality test was used. Since, for all variables, the test had a non-normal distribution (Field, 2011). With the answers obtained, it was necessary to use the Spearman correlation coefficient. To calculate these measures, the IBM SPSS Statistics version 22 software was used.

Researchers send the questionnaire to employees in the departments and sectors: Board, Sales, Marketing, RD\&I, Supplies/Logistics, Quality Management, Financial, Environmental, Industry/Production/Production Control Planning (PCP), Accounting/Costs, Maintenance, and Engineering.

Researchers structured the questionnaire in Google Forms. The participants received the questionnaire through WhatsApp and Teams (both communication apps) and corporate and personal e-mail. Of the 58 participants invited to participate, 27 participants responded to this research.

\section{Result and Discussion}

Frimesa is a Central Cooperative Company responsible for food production involving 3,435 integrated producers from five affiliated cooperatives (Copagril, Lar, Copacol, C.Vale, and Primato). It has 8,355 employees and a network of 36,232 thousand customers (distributors/resellers). It is the fourth largest pork industry in Brazil. It generated R \$ 4.29 billion in net revenue in 2020 , with $17.58 \%$ of this revenue referring to exports to 22 countries. It has 949 integrated swine producers, 2,486 milk producers, produce 412.7 thousand tons of food in 2020. Received 1,985,338 swine for slaughter and processing and industrialized 843,661 liters of milk, managing in 2020 to distribute a profit of R\$ 202 to associates .2 million (Frimesa, 2021b).

In the analysis of the study results, we initially sought to characterize the respondents, identifying their level of education and the sector of the company where they work. Figure 1 shows the level of education. 


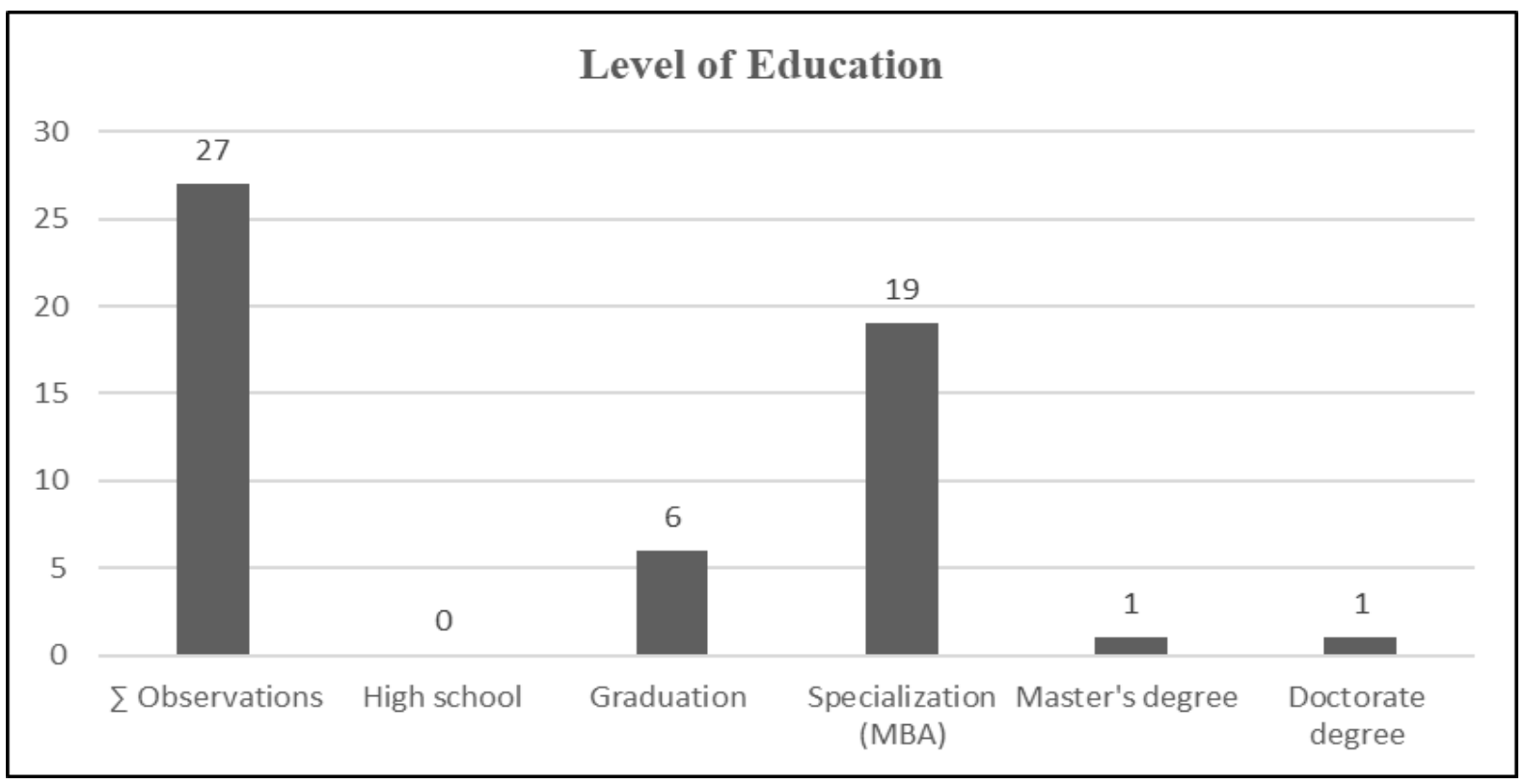

Figure 1. Level of Education

Source: Survey data (2021)

Most respondents have a specialization degree (70\%), 22\% have only a graduation degree, and $8 \%$ have specialization MBA, $4 \%$ master level, and $4 \%$ doctoral level. Due to the level of instruction of the personnel involved in forming a new product, it is expected that most of them know the object of the study. Figure 2 shows the sector of the company in which the respondent works.

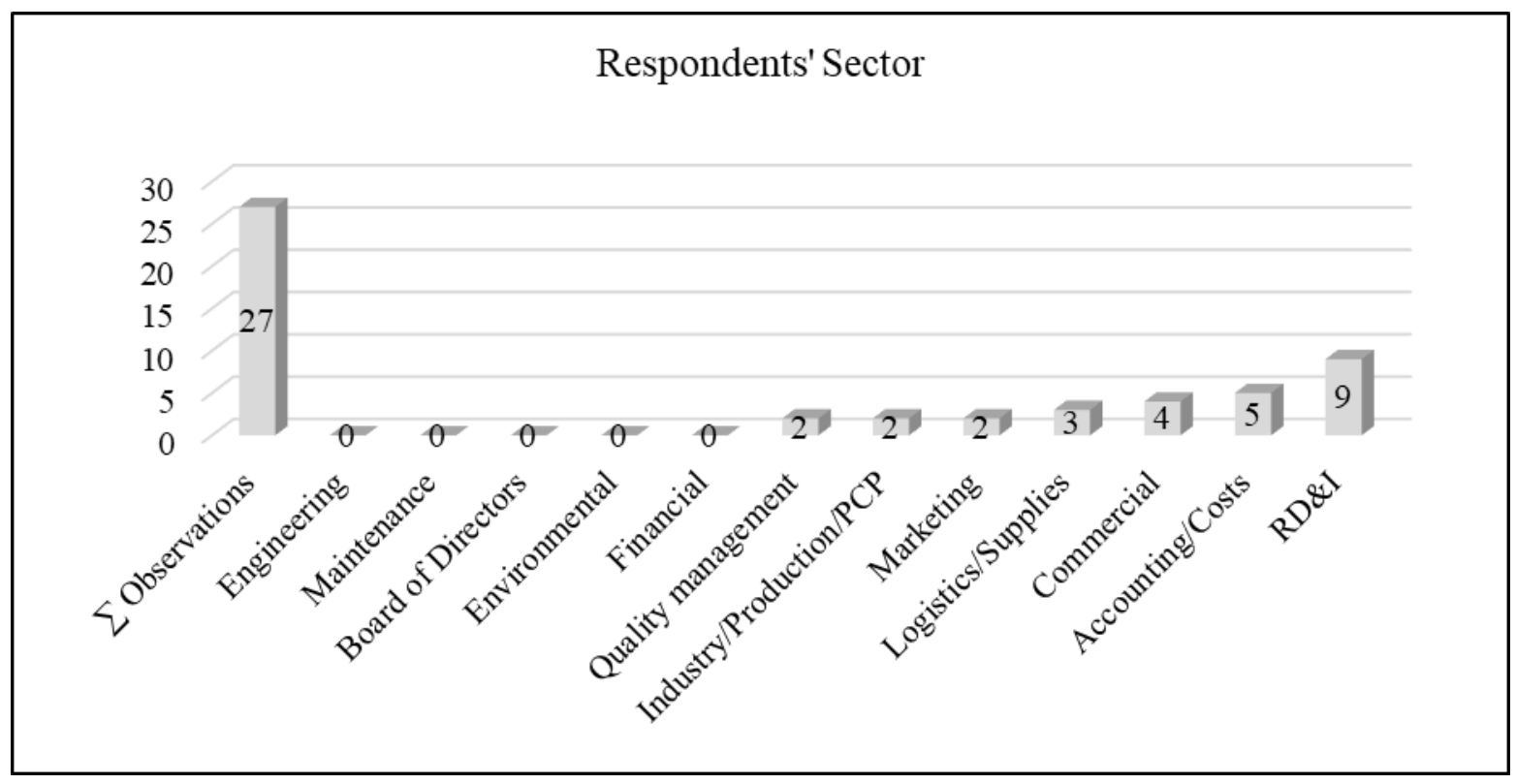

Figure 2. Sector in which the respondent works in the company

Source: Survey data, 2021

As expected, the sector with the highest number of respondents is RD\&I, which corroborates 
the respondents' results about which areas in their perception should be involved in the company's new product development process (Figure 7).

Unlike expected, there was no participation from the Engineering sectors, Maintenance, Environmental Management, and Financial. According to Krishnan and Ulrich (2001), this is a problem. The author said that product development and production activities are often distributed between company sectors instead of a single sector carrying them out in an integrated manner. Since the launch of a new product, considering the company's area of operation requires the participation of these sectors (Krishnan Ulrich, 2001).

Continuing the study, by applying a structured questionnaire sought in its 1st step, researchers identify the respondents' knowledge concerning the object of study. The questionnaire uses the Likert scale to measure the respondents' degree of understanding. On this scale, respondents scored 1 for Total Unknown, 2 for Little Knowledge; 3 for Medium Knowledge; 4 for Good Knowledge; and 5 for Total Knowledge. Figure 3 presents the results.

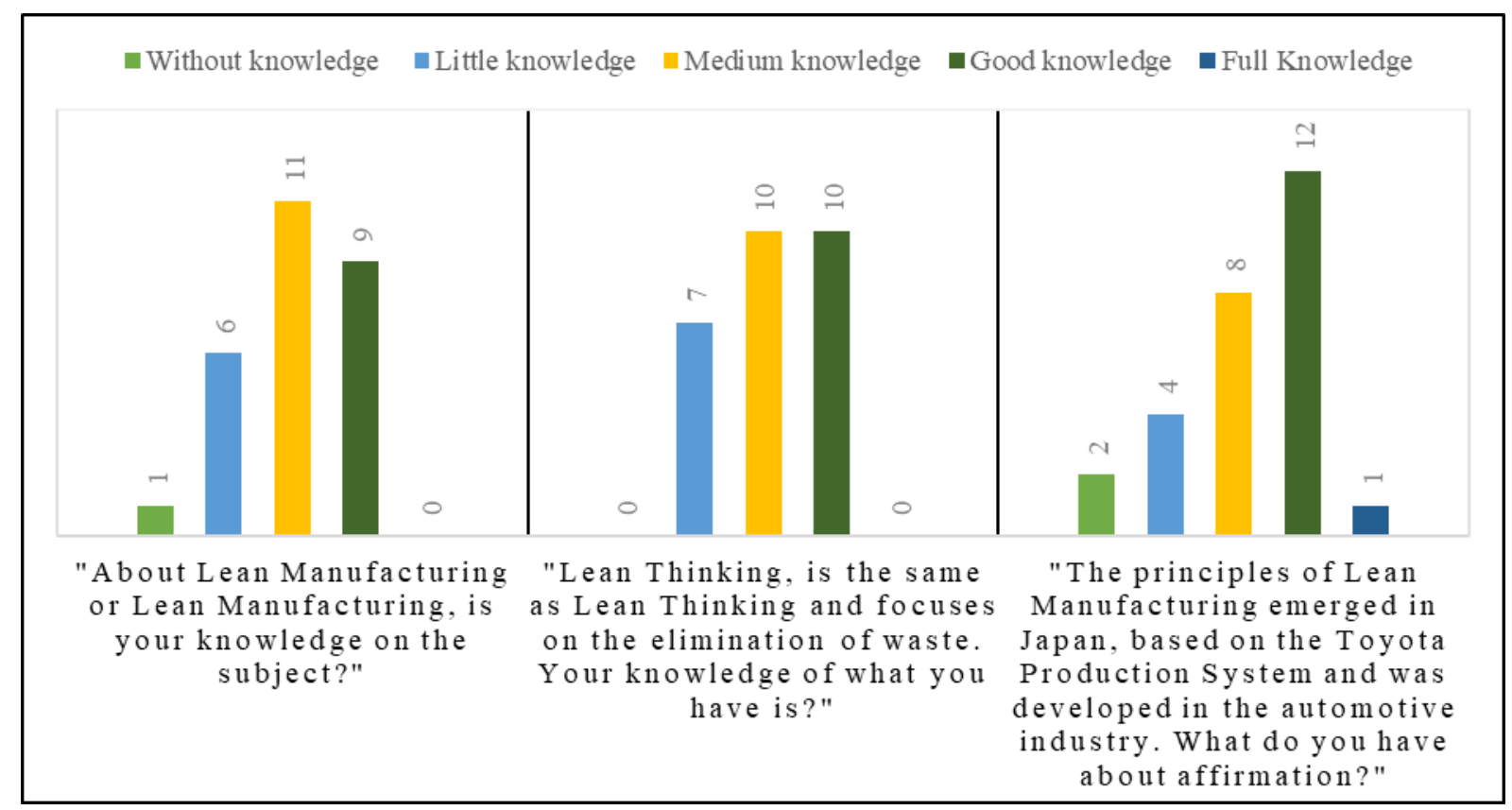

Figure 3. Level of knowledge of actors on the topic

Source: Survey data, 2021

The results showed that most participants (67\%) understand and know about Lean Manufacturing, although none have full knowledge.

Regarding the knowledge of LT, the results showed that participants understand the concepts and their goals. There is not any "total ignorance", and 1/4 of the participants have little knowledge. Still, also there is no "full knowledge" on the subject.

As refers to knowledge about "The principles of Lean Manufacturing," the results showed that two-thirds have good/average knowledge. This issue has a higher percentage of respondents with wholly or little knowledge, representing just over $1 / 5$ of respondents. 
Considering these results, for effective implementation of Lean Manufacturing, there is a need for alignment about human resources, which corroborates the study results by Simons and Taylor (2007).

In the 2nd stage, we sought to identify whether the respondent's understood LM and LT. The questionnaire uses the Likert scale and the other steps to measure respondents' degree of agreement. On this scale, respondents scored 1 for Totally Disagree; 2 for Partially Disagree; 3 for Don't Disagree and Don't Agree; 4 for Partially Agree; and 5 for Totally Agree. Figure 4 presents the results.

"The 5 (five) principles of Lean Thinking are: Identify value, Map value stream, Create continuous flow, establish pulled production, seek perfection."

"The lean thinking philosophy is to eliminate waste, reduce the number of failures, increase inventory turnover, decrease production costs and improve customer service and relationships."

"Lean Thinking is a work philosophy that puts some basic principles into practice and means creating more value for customers, with fewer resources."

"To gain competitive advantage, some companies adopt Lean Manufacturing. Methodology that allows increased production, reduces costs, improves the quality of products and services and...
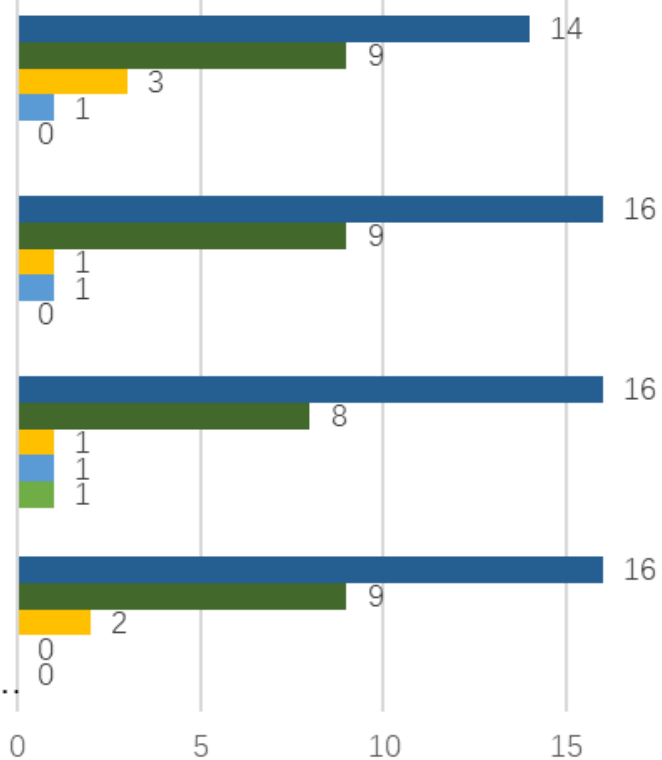

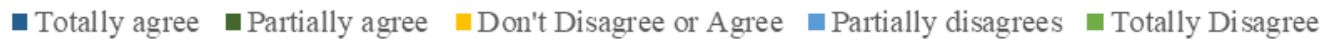

Figure 4. Agreement of respondents about theme assertive

Source: Survey Data (2021)

For the statement, "To gain competitive advantage, many companies adopt Lean Manufacturing. This methodology allows companies to increase production, reduce costs, improve the quality of products and services, and increase profits. About the statement you:", the respondents understand the LM methodology and its objectives and results when applied.

For the question, "Thinking Lean is a work philosophy that puts into practice some basic principles and means creating more value for customers, with fewer resources. About the statement you", the participants demonstrated that they mostly agree that LT is a philosophy that aims to create value for customers with fewer resources.

For the statement, "The LT philosophy consists of eliminating waste, reducing the number of failures, increasing stock turnover, decreasing production costs, and improving customer 
service and relationship. About the statement you:", the result demonstrates the agreement that LT is a philosophy to eliminate waste, reduce failures in the process, to analyze, and to take care of stocks, aiming to reduce costs and serve the end customer well.

As for the question "The 5 (five) principles of LT: Identifying value, Mapping the value stream, creating continuous flow, establishing pull production, Pursuing perfection. About the statement you:", demonstrates that most respondents agree with the statement of the Five Principles of LT. In general, although there are people in the company who do not have any knowledge or little knowledge, most $70 \%$ have good or complete knowledge.

In the 3rd stage, the questionnaire uses the Likert scale to measure respondents' degree of agreement on the existence of the LM and LT process in the company. Figure 5 shows the results.

"Is there a concern in the company about eliminating waste during the process of developing new products?"

"Are there tools used to map and analyze the flow of information in the process of developing new products in the company?".

"Regarding the processes and methodologies used in the development of new products in the company, are they reviewed in order to obtain improvements in the flow of activities and eliminate information that...

"The stages of the process of developing new products in the company, is understood and followed by all areas involved".

"Is there a formalized process or method in the company in the development of new products?"

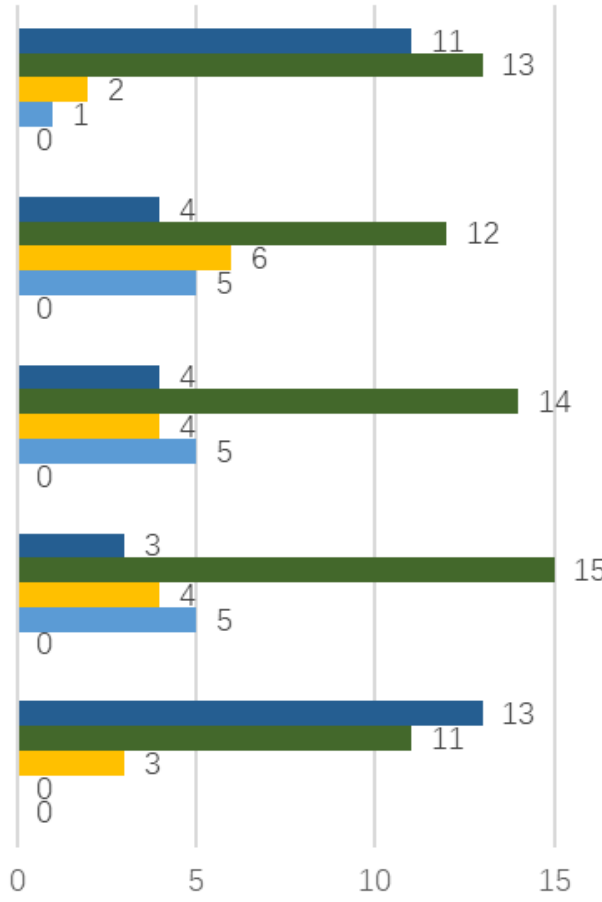

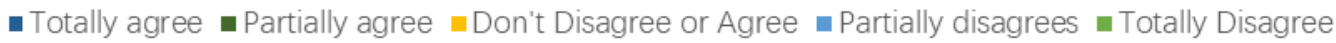

Figure 5. Existence of the Lean (Manufacturing and Thinking) process in the company Source: Survey Data (2021)

Regarding "Is the company concerned about eliminating waste during the new product development process?", most respondents perceive that the company is concerned about eliminating waste during the new product development.

Regarding the question whether "There are tools used for mapping and analyzing the flow of information in the process of developing new products in the company", the interviewees, in their perception, agree on the possibility of using LM tools for the development process of new products in the company. 
As for, "Concerning the processes and methodologies used in the development of new products in the company, are they revised to obtain improvements in the flow of activities and eliminate information that does not add value?", in the interviewees' perception of the methodologies in some currently they are not reviewed to obtain improvements in the flow of activities and eliminate information that is sometimes unnecessary and does not add value to the process.

About the question "The steps in new products development process in the company are understood and followed by all areas involved". Interviewees' perception is that the company doesn't entirely understandunderstand the new product development process stages.

Concerning: "Is there a formalized process or method in the company for developing new products?", the results show that the respondents understand some formalized process or method for developing new products in the company.

As expected, the results demonstrate that not all employees fully know the existence of LM and LT. These results are justified by not being institutionalized in the company.

The 4th stage of the research seeks to find out if new products development processes are integrated into the areas involved and whether there is sharing with stakeholders and the company's senior management.

"Are stakeholders (affiliates, suppliers, employees, customers, etc.) involved in deciding on the processes of developing new products in the...

"Are the initial concerns of stakeholders about the design and specifications in the development of new products in the company considered and...

"Is there the involvement of senior management (Board) in all stages of the process of developing new products in the company?"

"Are there traditional meetings (face-to-face meetings) between areas for information sharing and/or decision-making in the company?"

"Is there integration between the areas for the process of developing new products in the company?"

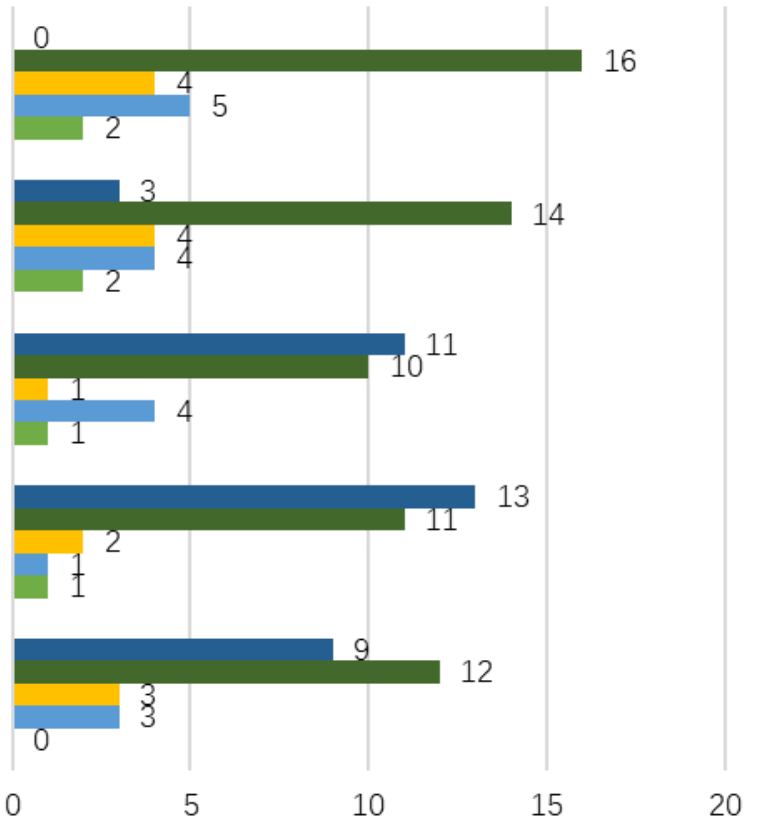

-Totally agree $\quad$ Partially agree $\quad$ Don't Disagree or Agree $\square$ Partially disagrees $\backsim$ Totally Disagree

Figure 6. Sharing with stakeholders in the development of new products

Source: Survey data (2021) 
Regarding the question "Are the stakeholders (affiliates, suppliers, employees, customers, etc.) involved in the decision regarding the company's new product development processes?", the respondents' perception demonstrates that the stakeholders are not very involved in the stages of the company's new product development process.

The participation of stakeholders is essential for two reasons: first, to include the specific needs of organizations about the understanding of LT; second, the creation of Value in the product development process is possible only when there is a mutual agreement (tacit or explicit) between the key stakeholders (Murman et al., 2002; Simons; Taylor, 2007; Monaj et al., 2016).

Regarding the question "Are stakeholders' initial concerns about design and specification in developing new products in the company considered and incorporated into the process as early as possible?". Respondents' perception showed that concerns about the design and specification of stakeholders are not considered in their entirety as soon as possible, which is observed by the expressive result for the "partially agrees" option.

In many cases, product development involves multiple stakeholders at each stage of development. As the complexity of the system increases, more stakeholders become involved, and the effort to manage the organization grows (Stanke, 2001). A stakeholder is any group or individual that affects or is affected by the achievement of organizational objectives (Stanke, 2001).

About the question "Is there the involvement of senior management (Board) in all stages of the process of developing new products in the company?". The board is somehow involved. However, there are indications that it would not be in its entirety in all stages of the process due to the percentage added between the alternatives Partially Agree, Partially Disagree, and Totally Disagree. This item needs to be worked on by the company, as Monaj et al. (2016), demonstrated that the lack of active involvement of senior management results in limited success in implementing LM.

Regarding whether "Are there traditional meetings (face-to-face meetings), between areas for sharing information and decision making in the company?". For respondents, there are formal meetings between areas to share or decide on the information.

Regarding "Is there integration between the areas for the process of developing new products in the company?", most respondents show that there is no integration between areas in its entirety for developing new products in the company.

Furthermore, respondents show which areas in their perception should be involved in its new product development process. Figure 7 shows the results. 


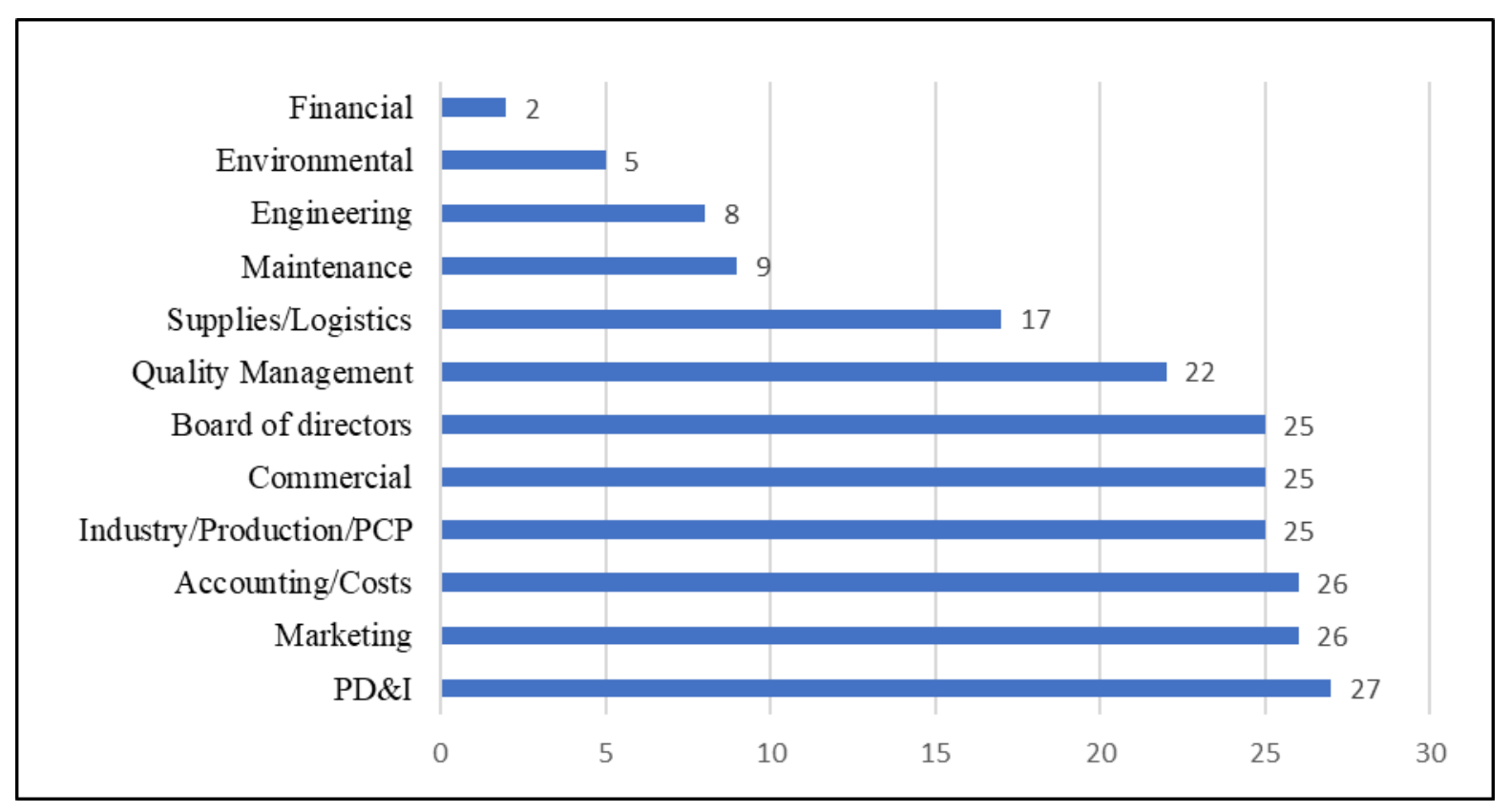

Figure 7. Areas that should be involved in the process

Source: Survey data (2021)

In the respondents' conception, RD\&I (100\%), Marketing and Accounting/Costs (96\%) and Management, Commercial and Industry/Production/PCO (93\%), must be involved in the design of a new product, which agrees with Monaj et al., (2016). They also said that the other sectors, although with lower percentages, should at some point, to a greater or lesser extent, be involved in developing new products in the company. These results contradict what Figure 2 shows. In the respondents' conception, the Engineering, Maintenance, Management, Environmental and Financial departments play an essential role in the product development process, but these sectors, although urged to participate in the study, omitted themselves.

Finally, the analysis of the relationship between each of the sets of questions was carried out, through correlation. The result is shown in Table 2 
Table 2. Correlation between themes

\begin{tabular}{|c|c|c|c|c|c|}
\hline & & $\begin{array}{c}\text { Level of } \\
\text { knowledge of } \\
\text { actors on the } \\
\text { topic }\end{array}$ & $\begin{array}{l}\text { Agreement of } \\
\text { respondents about } \\
\text { theme assertive. }\end{array}$ & $\begin{array}{l}\text { Existence of } \\
\text { the Lean (M. } \\
\text { and T.) } \\
\text { process in the } \\
\text { company }\end{array}$ & $\begin{array}{l}\text { Sharing with } \\
\text { stakeholders in the } \\
\text { development of } \\
\text { new products. }\end{array}$ \\
\hline \multirow{3}{*}{$\begin{array}{l}\text { Level of knowledge } \\
\text { of actors on the } \\
\text { topic (Theme 1) }\end{array}$} & $\begin{array}{l}\text { Correlation } \\
\text { Coefficient }\end{array}$ & 1 & 0,103 & $-0,124$ & 0,1 \\
\hline & Sig. (2 ends) & & 0,609 & 0,538 & 0,621 \\
\hline & $\mathrm{N}$ & 27 & 27 & 27 & 27 \\
\hline $\begin{array}{l}\text { Agreement of } \\
\text { respondents about }\end{array}$ & $\begin{array}{l}\text { Correlation } \\
\text { Coefficient }\end{array}$ & 0,103 & 1 &, $696^{* *}$ &, $642^{* *}$ \\
\hline theme assertive. & Sig. (2 ends) & 0,609 & & 0 & 0 \\
\hline (Theme 2) & $\mathrm{N}$ & 27 & 27 & 27 & 27 \\
\hline $\begin{array}{c}\text { Existence of } \\
\text { the Lean (M. and T.) }\end{array}$ & $\begin{array}{l}\text { Correlation } \\
\text { Coefficient }\end{array}$ & $-0,124$ & ,696 & 1 &, $687^{* *}$ \\
\hline process in the & Sig. (2 ends) & 0,538 & 0 & & 0 \\
\hline company (Theme 3) & $\mathrm{N}$ & 27 & 27 & 27 & 27 \\
\hline $\begin{array}{c}\text { Sharing with } \\
\text { stakeholders in the }\end{array}$ & $\begin{array}{l}\text { Correlation } \\
\text { Coefficient }\end{array}$ & 0,1 &, $642^{* *}$ &, $687^{* *}$ & 1 \\
\hline development of new & Sig. (2 ends) & 0,621 & 0 & 0 & \\
\hline $\begin{array}{l}\text { products. } \\
\text { (Theme 4) }\end{array}$ & $\mathrm{N}$ & 27 & 27 & 27 & 27 \\
\hline
\end{tabular}

Source: Survey data (2021)

Theme 1, which corresponds to the respondents' knowledge shown in Figure 3, did not present a statistically significant correlation with any of the other themes.

Theme 2, as shown in Figure 4, which sought to identify whether there is an understanding of what LM and LT consists of, by the respondents, presented a statistically significant correlation with themes 3 and 4. Theme 3, as shown in Figure 5, sought to identify the existence of the LM and LT process in the company. Theme 4, as shown in Figure 6, sought to find out if the process is integrated in the areas involved in the development of new products, as well as if there is sharing with the stakeholders and the company's top management. In addition, theme 3 and 4 also showed correlations with each other.

Given the above, it is possible to infer that the greater the level of understanding of the respondents, the greater the level of application of LT techniques.

\section{Conclusion}

This study sought to understand the perception and understanding of the interviewed participants regarding their knowledge of LM and LT in the development of new products at Frimesa company. 
The study showed that most respondents have participated at some level in developing new products at the Frimesa company. This process is not totally unknown to most. Only a percentage of $11.1 \%$ of respondents never participated and had any involvement in new products in the company. The fact that there are recent employees in the company may explain that.

Most respondents have knowledge and understanding about LM and the philosophy of LT. As for lean practices applied in new products development, they perceive the existence of some method and process formalized in the company. However, these practices are not fully understood and followed by all areas. What may explain this is that the process is not yet institutionalized in the company.

Participants showed that the company's methodologies adopted and applied are not revised to improve the flow of activities and eliminate unnecessary information and waste. Most agree with the possibility of using LM tools to map and analyze the value stream in the company's new product development process stages.

In the interviewees' perception, there is little involvement and participation of stakeholders in the process stages. There is little integration between areas. Still, they expressed that traditional meeting occur for its new product development process, with RD\&I, Marketing, Costs, Commercial, Production, and Management, with greater involvement in the process.

This study contributed by raising data on employees' perception regarding their knowledge in management and lean practices used in the stages of the new product development. It indicates the need for an incursion into LM and LT by the Frimesa company. It also shows their respective analyzes to the sectors and personnel involved in the process.

As a limitation of the research, the single case study stands out, with a non-random sample of respondents, which, although it cannot be generalized, does not invalidate the results found. Future studies replicated in companies with similar activities that have not yet implemented LM will help increase understanding in the field.

\section{References}

Al-Ashaab, A., \& Sobek, D. K. (2013). Lean product and process development: a value creation paradigm that goes beyond lean manufacturing. International Journal of Computer Integrated Manufacturing, 26(12), 1103-1104. https://doi.org/10.1080/0951192X.2013.834483

Babbie, E. Métodos de Pesquisas de Survey. 1999. Belo Horizonte: Editora UFMG, 113-158.

Basu, P., Ghosh, I., \& Dan, P. (2018). Using structural equation modeling to integrate human resources with internal practices for lean manufacturing implementation. Management Science Letters, 8(1), 51-68. https://doi.org/10.5267/j.ms1.2017.10.001

Bozdogan, K., Milauskas, R., Mize, J., Nightingale, D., Taneja, A., \& Tonaszuck, D. (2000). Transição para uma Lean Enterprise: Um Guia para Líderes, Volume III, Explorações de Roteiro. http://hdl.handle.net/1721.1/81894 
Brettel, M., Friederichsen, N., Keller, M., \& Rosenberg, M. (2017). How virtualization, decentralization and network building change the manufacturing landscape: an industry 4.0 perspective. FormaMente, 12.

Browning, T. (2001). Complex System Product Development: Adding Value by creating information and reducing risk. Lean aerospace initiative report WP99-03. Cambridge.

Cherrafi, A., Elfezazi, S., Chiarini, A., Mokhlis, A., \& Benhida, K. (2016). A integração da manufatura enxuta, six sigma e sustentabilidade: uma revisão da literatura e futuras direções de pesquisa para o desenvolvimento de um modelo específico. Journal of Cleaner Production, 139, 828 846. https://doi.org/10.1016/j.jclepro.2016.08.101

Dora, M., Kumar, M., \& Gellynck, X. (2016). Determinants and barriers to lean implementation in food-processing SMEs-a multiple case analysis. Production Planning \& Control, 27(1), 1-23. https://doi.org/10.1080/09537287.2015.1050477

Farfan-Quintanilla, Z., Caira-Jimenez, M., Sotelo-Raffo, F., Raymundo-Ibañez, C., \& Perez, M. (2020, February). Applying SLP in a lean manufacturing model to improve the productivity of furniture SME. In International Conference on Intelligent Human Systems Integration (pp. 690-696). Springer, Cham. https://doi.org/10.1007/978-3-030-39512-4_106

Field, A. (2011). Discovering statistics using SPSS. Porto Alegre: Bookman.

Frimesa Central Cooperative. (2021b). Report The annual 2019- 2020. Available at: report_sustentabilidade_2019_2020_41-23-89.pdf. Access Jul 1, 2021.

Frimesa Central Cooperative. (2021a). Think Lean Program. Available at: https://www.frimesa.com.br/pt/noticia/programa-pensar-enxuto. Access Jul 1, 2021.

Fullerton, R. R., Kennedy, F. A., \& Widener, S. K. (2013). Management accounting and control practices in a lean manufacturing environment. Accounting, Organizations and Society, 38(1), 50-71. https://doi.org/10.1016/j.aos.2012.10.001

Fullerton, R. R., Kennedy, F. A., \& Widener, S. K. (2014). Lean manufacturing and firm performance: The incremental contribution of lean management accounting practices. Journal of Operations Management, 32(7-8), p. 414-428, 2014. https://doi.org/10.1016/j.jom.2014.09.002

Gandhi, N. S., Thanki, S. J., \& Thakkar, J. J. (2018). Ranking of drivers for integrated lean-green manufacturing for Indian manufacturing SMEs. Journal of Cleaner Production, 171, 675-689. https://doi.org/10.1016/j.jclepro.2017.10.041

Gil, A.C. (2010) How to design research projects. 5. ed. São Paulo: Atlas, 2010.

Gurumurthy, A., \& Kodali, R. (2009). Application of benchmarking for assessing the lean manufacturing implementation. Benchmarking: An International

Journal. https://doi.org/10.1108/14635770910948268

Iris, C., \& Cebeci, U. (2014). Analyzing the relationship between ERP utilization and lean manufacturing maturity of Turkish SMEs. Journal of Enterprise Information Management. 
https://doi.org/10.1108/JEIM-12-2013-0093

Jugend, D., \& Da Silva, S. L. (2014). Integration of R\&D and New product development: case studies of Brazilian high-tech firms. International Journal of Business Innovation and Research, 8(4), 422-439. https://doi.org/10.1504/IJBIR.2014.063071

Kaplan, R. S; Norton, D. P. (2004). Strategic maps: converting intangible assets into tangible results. 6. ed. Rio de Janeiro: Elsevier.

Kilpatrick, A. M. (1997). Lean manufacturing principles: a comprehensive framework for improving production efficiency (Doctoral dissertation, Massachusetts Institute of Technology).

Kotler, P. (2000). Marketing Administration. 10. ed. São Paulo: Prentice Hall.

Krishnan, V., \& Ulrich, K. T. (2001). Product development decisions: A review of the literature. Management Science, 47(1), 1-21. https://doi.org/10.1287/mnsc.47.1.1.10668

Lambin, J. J. (2013). Changing market relationships in the internet age. Presses Univ. of Louvain, 2013.

León, H. C. M., \& Farris, J. A. (2011). Lean product development research: Current state and future directions. Engineering Management Journal, 23(1), 29-51. https://doi.org/10.1080/10429247.2011.11431885

Liker, J. K., \& Morgan, J. (2011). Lean product development as a system: a case study of body and stamping development at Ford. Engineering Management Journal, 23(1), 16-28. https://doi.org/10.1080/10429247.2011.11431884

Lucato, W. C., Calarge, F. A., Junior, M. L., \& Calado, R. D. (2014). Performance evaluation of lean manufacturing implementation in Brazil. International Journal of Productivity and Performance Management.

Machado, M. C., \& Toledo, N. N. (2008). Product development process management: an approach based on value creation. São Paulo: Atlas.

Martins, P. G., \& Laugeni, F. P. (2012). Production Management. 2nd ed. São Paulo: Saraiva.

Mattar, F. N. (2001). Marketing Research. Compact Edition. 3rd ed. São Paulo: Atlas.

Miguel, P. A. C. (2009). QFD in new product development: a study on its introduction in a company adopting action-research as the methodological approach. Production, 19(1), 105-128. https://doi.org/10.1590/S0103-65132009000100008

Morgan, J. M., \& Liker, J. K. (2006). The Toyota Product Development System. Target, 22(4). https://doi.org/10.4324/9781482293746

Mostafa, S., Dumrak, J., \& Soltan, H. (2013). A framework for implementing lean manufacturing. Production \& Manufacturing Research, 1(1), 44-64. https://doi.org/10.1080/21693277.2013.862159 
Murman, E. et al. (2002). Value in Aerospace Industry. Palgrave: New York.

Nazareno, R. R., Silva, A. L., \& Rentes, A. F. (2003). Value stream mapping for products with a wide range of parts. In: National Meeting of Production Engineering, 23. Ouro Preto. Electronic proceedings. Rio de Janeiro: ABEPRO.

Quintella, H. L. M. M., \& Rocha, H. M. (2007). Level of maturity and comparison of PDPs for automotive $\quad$ products. Production, $\quad 17(1), 199-217, \quad$ Jan./Apr. https://doi.org/10.1590/S0103-65132007000100014

Rymaszewska, A. D. (2014). The challenges of lean manufacturing implementation in SMEs. Benchmarking: An International Journal. https://doi.org/10.1108/BIJ-10-2012-0065.

Sanders, A., Elangeswaran, C., \& Wulfsberg, J. P. (2016). Industry 4.0 implies lean manufacturing: Research activities in industry 4.0 function as enablers for lean manufacturing. Journal of Industrial Engineering and Management (JIEM), 9(3), 811-833. https://doi.org/10.3926/jiem.1940

Santos, R.V. (2010). Evidence of lean accounting in lean companies: an exploratory case study. Proceedings of the XVII Brazilian Congress on Costs, Minas Gerais.

Simons, D., \& Taylor, D. (2007). Lean thinking in the UK red meat industry: a systems and contingency approach. International Journal of Production Economics, 106(1), 70-81. https://doi.org/10.1016/j.ijpe.2006.04.003

Stanke, A. K. (2001). A framework for achieving lifecycle value in product development (Doctoral dissertation, Massachusetts Institute of Technology). http://hdl.handle.net/1721.1/28239.

Stanke, A., \& Murman, E. (2001). A framework for achieving lifecycle value in aerospace product development. http://hdl.handle.net/1721.1/84147

Takahashi, S., \& Takahashi, V. (2007). Product innovation management: strategy, process, organization, and knowledge. Rio de Janeiro: Editora Campus.

Tortorella, G. L., \& Fettermann, D. (2018). Implementation of Industry 4.0 and lean production in Brazilian manufacturing companies. International Journal of Production Research, 56(8), 2975-2987. https://doi.org/10.1080/00207543.2017.1391420

Tyagi, S., Choudhary, A., Cai, X., \& Yang, K. (2015). Value stream mapping to reduce the lead-time of a product development process. International journal of production economics, 160, 202-212. https://doi.org/10.1016/j.ijpe.2014.11.002

Ulrich, K. T., \& Eppinger, S. D. (2004). Product design and development. 3. ed. New York: McGraw-Hill.

Wang, J. (2010). Lean Manufacturing: Bottom-Line Based Business. CRC Press. https://doi.org/10.1201/9781420086034

Werkema, C. (2011). Lean Six Sigma: Introduction to Lean Manufacturing tools. Rio de 
Janeiro (RJ): Elsevier, 17.

Womack, J. P., \& Jones, D. T. (1997). Lean thinking banishes waste and creates wealth in your corporation. Journal of the Operational Research Society, 48(11), 1148-1148. https://doi.org/10.1057/palgrave.jors.2600967

Womack, J. P., Jones, D. T., \& Roos, D. (1990). A machine that Changed the World. Simon and Schuster.

Womack, J. P., \& Jones, D. T. (2004). The lean mindset in companies: eliminate waste and create wealth. 6. ed. Rio de Janeiro: Elsevier.

\section{Copyright Disclaimer}

Copyright for this article is retained by the author(s), with first publication rights granted to the journal.

This is an open-access article distributed under the terms and conditions of the Creative Commons Attribution license (http://creativecommons.org/licenses/by/4.0/). 